\title{
Nehb 誘導に関する研究
}

\author{
第 二 編 \\ Nehb 誘導の臨床的意義 \\ 岡山大学医学部第一内科教室（主任：小坂淳夫教授） \\ 与那原 宣 彦 \\ (昭和 50 年 9 月 10 日受稿)
}

\section{緒言}

心電図から虚血性変化を推測する所見としては， ST-Tの変化が最も重要であるが,著者は第一編で, 虚血性心疾患患者の STベクトルは QRS ベクトル と約 $180^{\circ}$ 反対の，右前上方に向うことを指摘し，ま た, 日本成人男子胴体模型実験で Nehb のD誘導の QRS 波の transfer impedance vector $4 V_{5}, V_{6}$, $\mathrm{V}_{7}$ 誘導のそれょりも大きく，また，方向は $\mathrm{V}_{6} ， V_{7}$ ， とくに，V，誘導と平行に近いととから，Nehb-D誘 導は ST 変化を明確にとらえる,よりよい誘導であ ることを明らかにしたが，本編では臨床例について， 標準12誘導（安静時は $V_{7}$ 誘導も加えたので，以下 これらを標準13脬導と仮称する。）と，Nehb誘導 ${ }^{1,21}$ について，運動負荷前後の心電図を記録し，比較 検討したので報告する。

\section{对㽚と検查方法}

対象は表 1，2亿示す如くで，乙れらは岡大第一 内科受診患者で, 男性64人，女性72人の計136例で ある. 年令は19才から73才にわたり，平均年令は 49.2才である. 臨床診断名は冠不全, 高血圧, 狭心
症が多く，心筋硬塞例は含まれているい，

てれら136例に，運動負荷試験として，原則として Masterの double two-step testを行ないそその

\begin{tabular}{|c|c|c|}
\hline age & male & female \\
\hline-19 & 0 & 1 \\
\hline $20-29$ & 6 & 3 \\
\hline $30-39$ & 9 & 8 \\
\hline $40-49$ & 18 & 25 \\
\hline $50-59$ & 16 & 15 \\
\hline $60-69$ & 15 & 16 \\
\hline $70-$ & 0 & 4 \\
\hline total & 64 & 72 \\
\hline grand total & \multicolumn{2}{|c|}{136} \\
\hline
\end{tabular}

前後に, 標準12誘導 (安静時は前述の標準13誘導) と,Nehb の D, A, J 誘導心電図を記録した. 運動負 荷後の記録は, 直後, 3 分, 5 分後に行った.

心電図の判定基準は種々の問題の多いところであ ろが, ST-T の変化を中心に表 3,4 亿従って, 安 静時之負荷後の心電図を分類した。 また ST 変化に

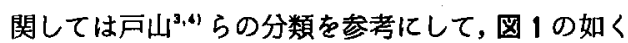
表 2 対象の疾患

Coronary insufficiency
Hypertension $\ldots \ldots \ldots \ldots \ldots \ldots \ldots \ldots$




\section{表 3 安静時心電図分類の判定基準}

Leads : I, II, aVl ( $\mathrm{R} \geqq \mathbf{5 m}$ ), aVF(QRS mainly upright), $\mathrm{V}_{\mathbf{3}-7}$, Nehb-D, A, J

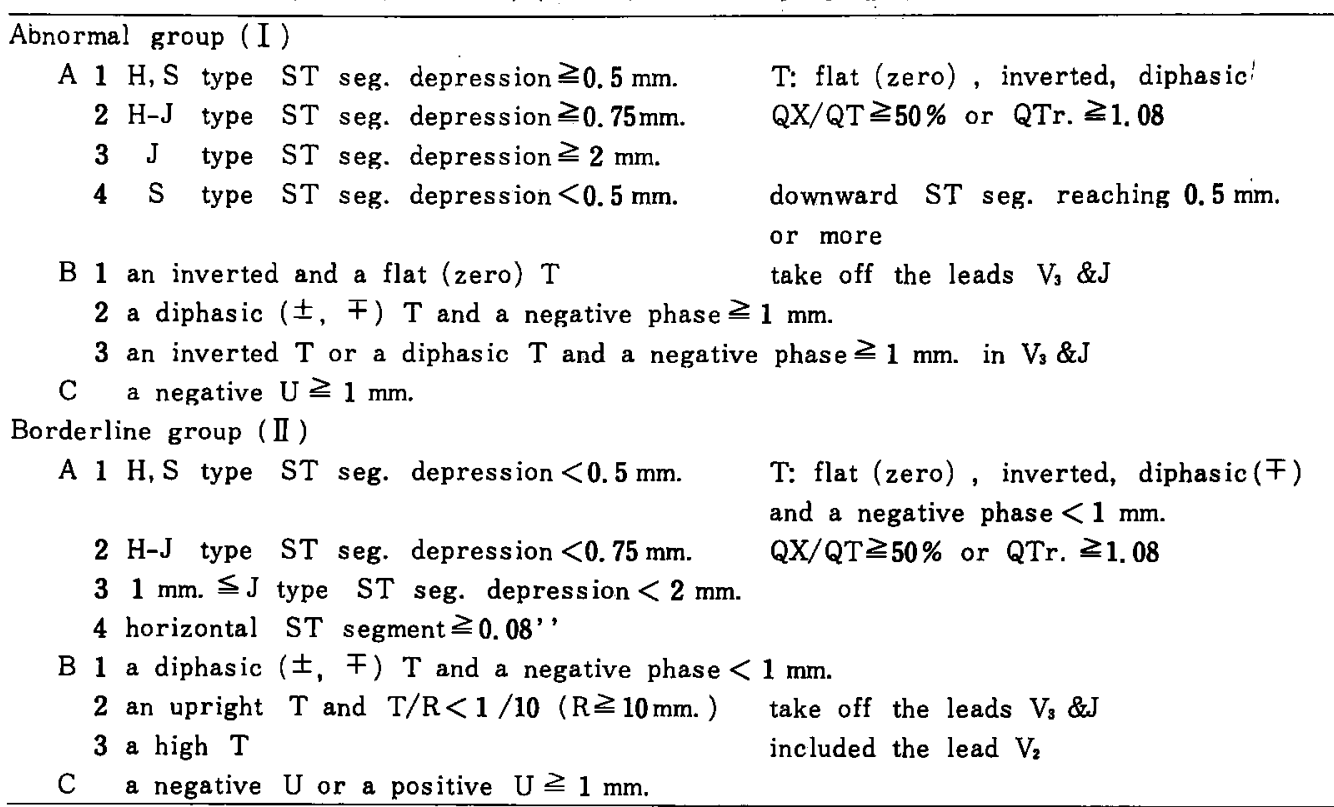

Fig 1 異常ST降下の型
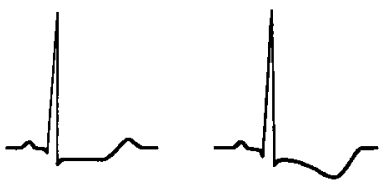

Horizontal type

$H$ type

$\geq 0.5 \mathrm{~mm}$.
Sagging type

S type

$\geq 0.5 \mathrm{~mm}$.

$<0.5 \mathrm{~mm}$. but

downward ST segment reaching $0.5 \mathrm{~mm}$. or more

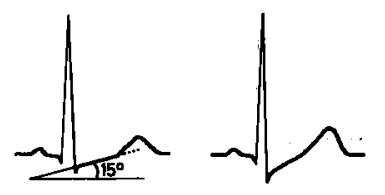

Junctional type H-J type I type

$\geq 0.75 \mathrm{~mm}$. Qx $>$ QT $\geq 50 \%$ CTr. $\geq 1.08$
にした。すなわち，HＪ型 ST 間部降下は ST-T 間部が基線となす角が15度以下のものである．ほか にST 間部盆状型降下があろが，それは horizontal type ( $\mathrm{H}$ type)，またはSagging type (S type) のST降下として取り扱い，ST-T間部で最も低い 所を測定した．ST の変化を求めるための基線(1は, Q-Q線"を採用した。 H J 型および J 型 ST降下 の junctional 部の測定点は原則として，QRS 棘波
のSから0.04秒の部としたが，症例によっては0.04 秒点にとらわれず, 変曲点としてょり要当と思われ ろ所を测定点とした。

$$
\text { 成 績 }
$$

1) Nehb 誘導の QRS 䊂波の波型の特徴 $\mathrm{Nehb}$ 誘導の QRS 棘波の特徴は表 5，6の通り で（q，sは 5 mm以下した。）Ｄ誘導は全例が 
表 4 運動負荷後心電図分類の判定基準

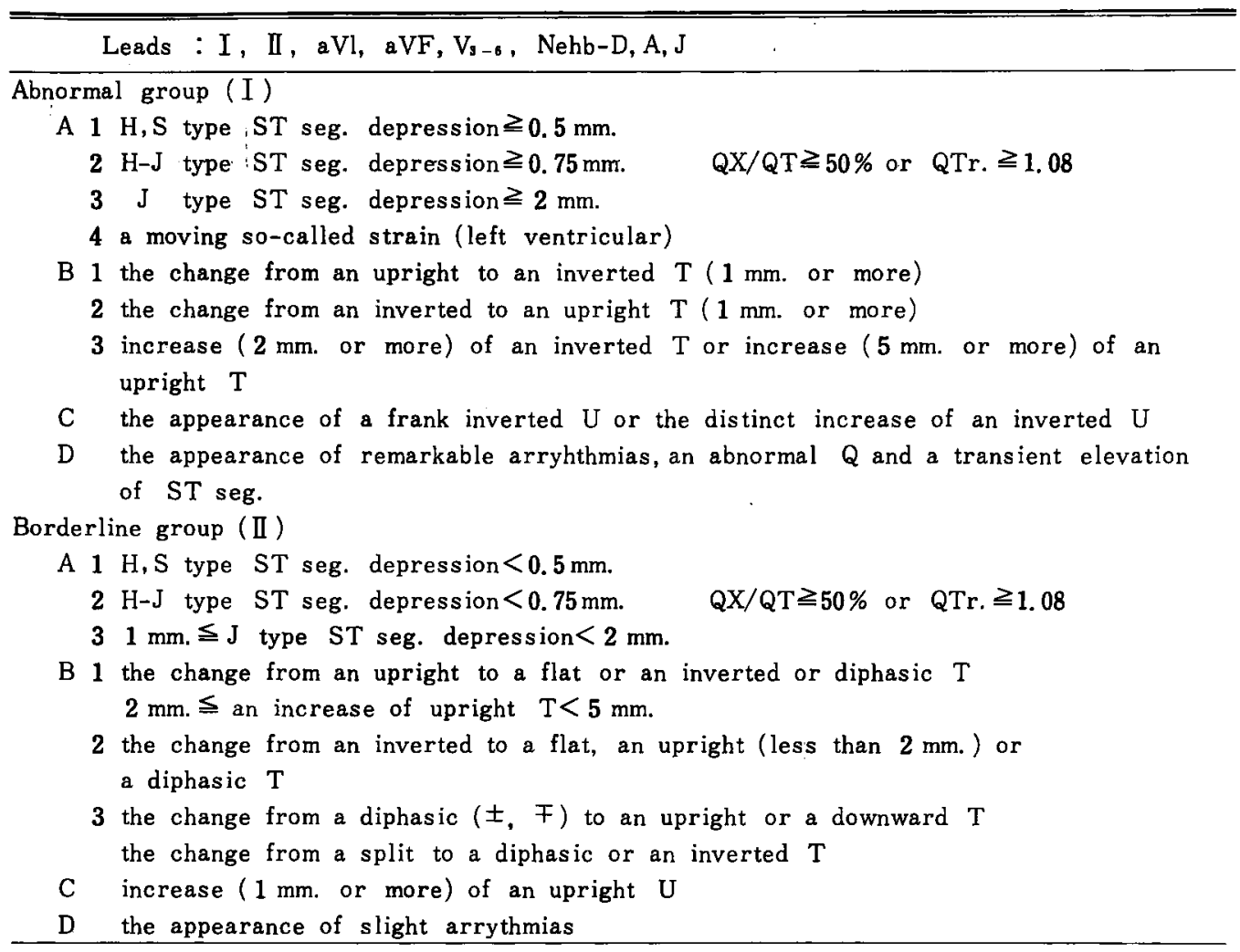

表 5 Nehb 誘導の QRS 梀波の型（その 1)

\begin{tabular}{c|c|c|c||c|c}
\hline \hline & $\begin{array}{c}\mathrm{q} \text { or } \mathrm{Q} \\
\text { (No. of cases) }\end{array}$ & $\begin{array}{c}\mathrm{R} / \mathrm{S}>1.0 \\
\text { (No. of cases) }\end{array}$ & $\begin{array}{c}\mathrm{R} / \mathrm{S} \leqq 1.0 \\
\text { (No. of cases) }\end{array}$ & $\begin{array}{c}\mathrm{S}=0 \\
\text { (No. of cases) }\end{array}$ & $\begin{array}{c}\mathrm{R} / \mathrm{S} \\
\text { (ratio) }\end{array}$ \\
\hline $\mathrm{D}$ & 132 & 136 & 0 & 92 & \\
$\mathrm{~A}$ & 89 & 133 & 3 & 14 & 11.1 \\
$\mathrm{~J}$ & 4 & 71 & 65 & 1 & 1.9 \\
\hline
\end{tabular}

表 6 Nehb 誘導の QRS 棘波の型（その 2)

\begin{tabular}{c|cccccccccc}
\hline \hline & $\mathrm{rs}$ & $\mathrm{rS}$ & $\mathrm{RS}$ & $\mathrm{Rs}$ & $\mathrm{R}$ & $\mathrm{qRS}$ & $\mathrm{qRs}$ & $\mathrm{QRs}$ & $\mathrm{qR}$ & $\mathrm{QR}$ \\
\hline \multirow{2}{*}{$\mathrm{J}$} & 4 & 14 & 98 & 15 & 1 & 3 & 1 & & & \\
& $(2.9)$ & $(10.3)$ & $(72.1)$ & $(11.0)$ & $(0.7)$ & $(2.2)$ & $(0.7)$ & & & \\
\hline \multirow{2}{*}{$\mathrm{A}$} & & & 30 & 14 & 3 & 29 & 46 & 3 & 11 & \\
& & & $(22.1)$ & $(10.3)$ & $(2.2)$ & $(21.3)$ & $(33.8)$ & $(2.2)$ & $(8.7)$ & \\
\hline $\mathrm{D}$ & & & & 3 & 1 & 1 & 38 & 2 & 84 & 7 \\
& & & & $(2.2)$ & $(0.7)$ & $(0.7)$ & $(27.9)$ & $(1.5)$ & $(61.8)$ & $(5.1)$ \\
\hline
\end{tabular}

$\mathrm{R} / \mathrm{S}$ 比が1.0 以上であり， $\mathrm{S}$ 波は 1 例に， $\mathrm{s}$ 波は43 例にみられるが，QRS 䊂波は $\mathrm{qR}$ 型と $\mathrm{QR}$ 型を加え たちのが91例にみられる。とくに $\mathrm{qR}$ 型が最も多く 136例中84例にみられた。 またqあるいはQ波を示 すちのは D誘導に多く，136例中132例 $(97.1 \%) に$
みられた，A誘導では， R/S 比が1.0以上のもの136 例中133例 $(97.8 \%)$ と，多く，QRS 棘波の形は

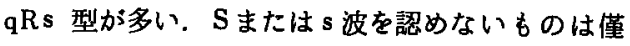
かに14例である。またqあるいはQ波を伴うものは 136例中89例にみられた。 J誘導では， R/S 比が1.0 
表 7 R 波高の平均值と標準偏差

(Nehb-D, A, J, V $, V_{6}, V_{7}$ )

\begin{tabular}{c|c}
\hline \hline & $($ Mean \pm S. D. $) \mathrm{mV}$ \\
\hline $\mathrm{V}_{5}$ & $2.14 \pm 0.69$ \\
$\mathrm{~V}_{6}$ & $1.68 \pm 0.53$ \\
$\mathrm{~V}_{7}$ & $1.25 \pm 0.38$ \\
$\mathrm{D}$ & $1.99 \pm 0.58$ \\
$\mathrm{~A}$ & $2.60 \pm 0.93$ \\
$\mathrm{~J}$ & $1.12 \pm 0.66$ \\
\hline
\end{tabular}

以上のものは136例中65例であり, QRS 棘波の形は， RS 型を示すものが98例（72.1\%) であった。また $\mathrm{q}$ あるいはQ波を伴う症例は少なく，4例にのみに みられた。

2) Nehb 誘導と標準誘導との関連性

$V_{5}, V_{6}, V_{7}, D, A, J$ 誘導の R 波の高さの平均值と 標準偏差は表 7 の通りで，大きさは $\mathrm{A}$ 誘導が最も大 きく, ついで $\mathrm{V}_{5}, \mathrm{D}, \mathrm{V}_{6}, \mathrm{~V}_{7}, \mathrm{~J}$ 誘導の順であり，D 誘導の大きさは $V_{7}$ 誘導のそれよりも大である.

つぎ波型について，Nehb誘導と標準13誘導と

Fig 2 標準誘導とNehb誘導の波形の類似性.

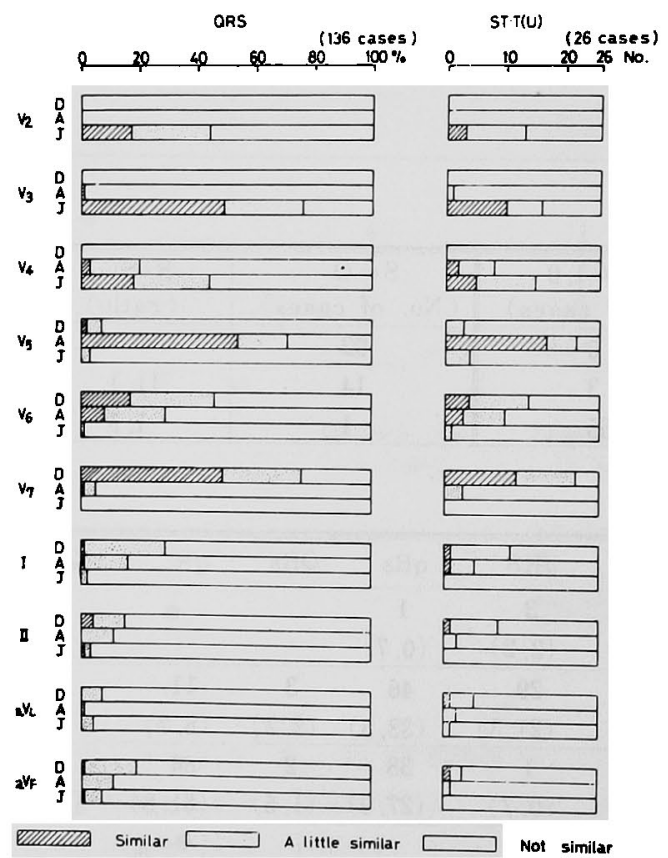

の間の類似性について検討すると，図 2 の通りであ る.そのさいQRS 棘波については全例, ST-T, U 波については標準13誘導で異常のみられた26例につ いて検討した. 判定に際しては, $\mathrm{q}$ s 波の有無, $\mathrm{q}$ と $\mathrm{s}$ の大きさの比, $\mathrm{R} \mathrm{S}$ 波の大きさの割合など
を参考とした。また ST-T（U）は異常な形態を参 考にして分類した。

まず，QRS 棘波についてみると，D誘導と最も類 似性の高い標準誘導は $V_{7}$ 誘導であり,ついで $V_{6}$ 誘 導であろ. $A$ 誘導については， $V_{s}$ 誘導が最も類似性 が高く,ついで $V_{6}$ 誘導である.J誘導については, $V_{3}$ 誘導が最も類似性が高く，ついで $V_{4}, V_{2}$ 誘導で ある.一般に標準肢誘導とNehb誘学の QRS 棘波 の波型の類似性は低い.

$\mathrm{ST}-\mathrm{T}, \mathrm{U}$ 波の変化についての標準誘導と Nehb 誘導との間の類似性については，QRS 䊂波の場合と 同様な傾向がみられたが,その類似性は全般に低い.

3 ) 安静時および運動負荷試験（master の double two-step test)における標準12誘導と Nehb誘 導の関連性

心電図の判定は表 3，4の基準に従った．表 8 の 前半の如く，安静時に標準13誘導で異常を示したの は26例，境界域のものは70例，正常例は40例であっ た。これに対して，Nehb誘導でみると，明らかな 異常例は59例（うちD誘導の ST 変化を示すものは 55例），境界域のものは48例（うちD誘導の ST 境 界変化は35例)，正常は29例であった。 すなわち， 異常出現率は標準13誘導よりも Nehb 誘導に高度で あった。

安静時心電図で異常を示した26例について Nehb 誘導における異常出現誘導を検討してみると表 9 の 通り，標準13誘導における異常の内容は，ST降下 が22例， T波の異常が4例である．との22例のうち $\mathrm{D}$ 誘導に ST 変化を認めたものは19例で, 残りの3 例はII，III， $a \mathrm{~V}_{F}$ 誘導にのみ $\mathrm{ST}$ 変化を認めた 5 例 のうちの3例であったままた，この22例のA誘導の $\mathrm{ST}$ 変化は11例，J誘道の ST 変化は 3 例である. 標準13誘導で T波の変化を示した 4 例は主として $\mathrm{V}_{3}, \mathrm{~V}_{4}$ 誘導を中心とした変化であったが,それらの Nehb 誘導における変化はD誘導にはみられず, A 誘導に 2 例, J誘導に 3 例であった。

安静時心電図の22例の ST 変化例のうち, II, II, $a V_{F}$ 誘導にのみ異常を認めた 5 例と, 境界域の変化 を示した 8 例の Nehb誘導における ST-T変化の誘 導を検討すると表10の通りで，D誘導で ST 変化を 認めたものは 2 例のみで A，J誘導では変化を認め なかった。 また境界域変化の8例のうち，D誘導で 4 例に異常を認めた.

$\mathrm{V}_{5}, \mathrm{~V}_{6}, \mathrm{~V}_{7}$ 誘導にのみ異常を認めた 8 例（全例 が主に ST変化）と, 境界域変化を示した17例の 
表 8 標準誘導と Nehb 誘導の運動負荷前後の心電図異常の出現頻度

\begin{tabular}{|c|c|c|c|c|c|c|c|c|c|c|}
\hline \multicolumn{5}{|c|}{ Resting } & \multicolumn{6}{|c|}{ After exercise } \\
\hline \multirow{2}{*}{\multicolumn{2}{|c|}{ Standard Lead }} & \multicolumn{3}{|c|}{ Nehb's Lead } & \multicolumn{3}{|c|}{ Standard Lead } & \multicolumn{3}{|c|}{ Nehb's Lead } \\
\hline & & $I$ & II & III & $\mathrm{I}$ & II & III & $\mathrm{I}$ & II & III \\
\hline I & 26 & 23 & 2 & 1 & 25 & 1 & 0 & 25 & 1 & 0 \\
\hline II & 70 & 31 & 37 & 2 & 31 & 32 & 7 & 54 & 13 & 3 \\
\hline III & 40 & 5 & 9 & 26 & 5 & 14 & 21 & 11 & 18 & 11 \\
\hline total & 136 & 59 & 48 & 29 & 61 & 47 & 28 & 90 & 32 & 14 \\
\hline \multicolumn{11}{|c|}{$\begin{array}{l}\text { I : abnormal group } \\
\text { II }: \text { borderline group } \\
\text { III : normal }\end{array}$} \\
\hline
\end{tabular}

表 9 標準誘導で異常心電図を示したもの (26例) の Nehb誘導の変化

\begin{tabular}{|c|c|c|c|c|c|c|c|c|c|c|c|c|c|c|c|c|c|c|}
\hline & \multicolumn{6}{|c|}{ D } & \multicolumn{6}{|c|}{$\mathrm{A}$} & \multicolumn{6}{|c|}{$\mathbf{J}$} \\
\hline & \multicolumn{3}{|c|}{$\mathrm{ST}$} & \multicolumn{3}{|c|}{$\mathrm{T}$} & \multicolumn{3}{|c|}{ ST } & \multicolumn{3}{|c|}{$T(U)$} & \multicolumn{3}{|c|}{ ST } & \multicolumn{3}{|c|}{$\mathrm{T}(\mathrm{U})$} \\
\hline & $I$ & II & III & $I$ & II & III & $I$ & II & III & $I$ & II & III & $\mathrm{I}$ & II & III & $I$ & II & III \\
\hline ST & 19 & 1 & 2 & 4 & 15 & 3 & 11 & 3 & 8 & $\begin{array}{c}2 \\
(\mathbf{1})\end{array}$ & $\begin{array}{c}3 \\
(1) \\
\end{array}$ & 15 & 3 & 1 & 18 & $\begin{array}{c}4 \\
(1)\end{array}$ & $\begin{array}{c}1 \\
(1)\end{array}$ & 15 \\
\hline $\begin{array}{c}\mathrm{T} \\
(\mathrm{U})\end{array}$ & 2 & 1 & 1 & 0 & $\begin{array}{c}3 \\
(1)\end{array}$ & 0 & 1 & 0 & 3 & 2 & 2 & 0 & 1 & 0 & 3 & 3 & 1 & 0 \\
\hline
\end{tabular}

$$
\begin{aligned}
& \text { I : abnormal group } \\
& \text { II }: \text { borderline group } \\
& \text { III }: \text { normal }
\end{aligned}
$$

\begin{tabular}{|c|c|c|c|c|c|c|c|c|c|c|c|c|c|c|c|c|c|c|}
\hline & \multicolumn{6}{|c|}{$\mathrm{D}$} & \multicolumn{6}{|c|}{ A } & \multicolumn{6}{|c|}{$\mathrm{J}$} \\
\hline & \multicolumn{3}{|c|}{$\mathrm{ST}$} & \multicolumn{3}{|c|}{$\mathrm{T}$} & \multicolumn{3}{|c|}{ ST } & \multicolumn{3}{|c|}{$\mathbf{T}$} & \multicolumn{3}{|c|}{ ST } & \multicolumn{3}{|c|}{$\mathrm{T}$} \\
\hline & I & II & & I & II & III & I & II & III & I & II & III & I & II & III & I & II & III \\
\hline A) & & & & & & & & & & & & & & & & & & \\
\hline ST & 2 & 1 & 2 & 1 & 1 & 3 & 0 & 2 & 3 & 0 & 0 & 5 & 0 & 0 & 5 & 0 & 1 & .4 \\
\hline B) & & & & & & & & & & & & & & & & & & \\
\hline ST & 4 & 4 & 0 & 0 & 4 & 4 & 0 & 0 & 8 & 0 & 0 & 8 & 0 & 0 & 8 & 0 & 0 & 8 \\
\hline
\end{tabular}

表10 II $, \mathbb{I I}, a \mathrm{~V}_{F}$ 誘導にのみ変化を認めた症例（異常群 $\mathrm{A} ， 5$ 例，境界群 B，8例）の Nehb 誘導の変化
A) : abnormal group
(in the standard lead)
B) : borderline group
I : abnormal group
II : borderline group
III : normal

(in the standard lead)

Nehb誘導における変化は表11に示す通りで，8例 の異常例は D誘導でも全例 ST 変化を認め, A誘導 では 5 例，J誘導では 1 例のみであった，境界域変 化を示した17例についてみると，D誘導では7例に $\mathrm{ST}$ 変化を認め，A，J誘導には変化を認めなかっ た.

つぎに, $V_{5}, V_{6}, V_{7}$ 誘導を含み他の誘導にも変 化を認めるもの, $V_{5}, V_{6}, V_{7}$ 誘導以外で変化を認 めるちの（II，III，aVF誘導のみの変化は除く）の 11例と, それらの Nehb誘導との関係は表12の通り で, この11例のうち ST 変化を示すちのは8例であ
ろが,これらは全例D誘導に同様な ST 変化を認め, 更にA誘導でも5例に ST変化を認めた。との11例 のうちT波の異常を示したのは 3 例で，その変化は A誘導で 2 例，J誘導で 3 例に認められた。

つぎに安静時心電図で Nehb 誘導に変化が認めら れた59例について，Nehb 誘導の各誘導との関係は 表13の如くである．STの異常はD誘導で55例（93. $2 \%), A$ 誘導で16例 (27.1\%)，J誘導で 4 例（6. 8\%)であり，压倒的にD誘導で変化が示された。

T波の異常を示したものは D誘導で10例，A誘導で 6 例，J誘導で 9 例であった。 
表11 $V_{5-7}$ 誘導にのみ変化を認めた症例（異常群 $\mathrm{A}, 8$ 例, 境界群 $\mathrm{B}, 17$ 例）の Nehb 認導の変化

\begin{tabular}{|c|c|c|c|c|c|c|c|c|c|c|c|c|c|c|c|c|c|c|}
\hline & \multicolumn{6}{|c|}{ D } & \multicolumn{6}{|c|}{ A } & \multicolumn{6}{|c|}{$\mathrm{J}$} \\
\hline & \multicolumn{3}{|c|}{ ST } & \multicolumn{3}{|c|}{$\mathrm{T}$} & \multicolumn{3}{|c|}{ ST } & \multicolumn{3}{|c|}{$T$} & \multicolumn{3}{|c|}{ S.T } & \multicolumn{3}{|c|}{$T$} \\
\hline & I & II & III & I & II & III & I & II & III & I & II & III & I & II & III & I & II & III \\
\hline A) & & & & & & & & & & & & & & & & & & \\
\hline $\mathrm{ST}$ & 8 & 0 & 0 & 2 & 6 & 0 & 5 & 1 & 2 & 2 & 2 & 4 & 1 & 0 & 7 & 4 & 0 & 4 \\
\hline B) & & & & & & & & & & & & & & & & & & \\
\hline $\mathrm{ST}$ & 7 & 6 & 2 & 2 & 3 & 10 & 0 & 1 & 14 & 0 & 0 & 15 & 0 & 0 & 15 & 0 & 0 & 15 \\
\hline $\mathrm{T}$ & 0 & 1 & 1 & 0 & 2 & 0 & 0 & 0 & 2 & 0 & 1 & 1 & 0 & 0 & 2 & 0 & 0 & 2 \\
\hline
\end{tabular}
A) : abnormal group
(in the standard lead)
B) : borderline group
I : abnormal group
II : borderline group
III : normal

(in the standard lead)

表12 $V_{5-7}$ と他の誘道にも異常を認めろ症例と $V_{5-7}$ 以外の誘導（II，II , $2 V_{F}$ は除く）で翼常を認める 症例 (計11例) の Nehb誘導の変化

\begin{tabular}{|c|c|c|c|c|c|c|c|c|c|c|c|c|c|c|c|c|c|c|}
\hline & \multicolumn{6}{|c|}{ D } & \multicolumn{6}{|c|}{ A } & \multicolumn{6}{|c|}{$\mathbf{J}$} \\
\hline & \multicolumn{3}{|c|}{ ST } & \multicolumn{3}{|c|}{$\mathrm{T}$} & \multicolumn{3}{|c|}{ ST } & \multicolumn{3}{|c|}{$T(\mathrm{U})$} & \multicolumn{3}{|c|}{ ST } & \multicolumn{3}{|c|}{$T(U)$} \\
\hline & I & II & III & I & II & III & I & II & III & I & II & III & I & II & III & & II & III \\
\hline ST & 8 & 0 & 0 & 2 & 6 & 0 & 5 & 0 & 3 & 1 & $\begin{array}{c}1 \\
(1)\end{array}$ & 5 & 0 & 1 & 7 & 2 & $\begin{array}{c}0 \\
\text { (1) }\end{array}$ & 5 \\
\hline $\begin{array}{c}\mathrm{T} \\
(\mathrm{U})\end{array}$ & 1 & 1 & 1 & 0 & $\begin{array}{c}2 \\
\text { (1) }\end{array}$ & 0 & 1 & 0 & 2 & 2 & 1 & 0 & 1 & 0 & 2 & 3 & 0 & 0 \\
\hline
\end{tabular}

I : abnormal group

I : borderline group

I : normal

表13 Nehb 誘導安静時異常例（59例）の内容

\begin{tabular}{|c|c|c|c|c|c|c|}
\hline & \multicolumn{3}{|c|}{ ST } & \multicolumn{3}{|c|}{$\mathrm{T}(\mathrm{U})$} \\
\hline & I & II & III & I & II & III \\
\hline \multirow{2}{*}{$\mathrm{D}$} & 55 & 2 & 2 & $10(1)$ & $39(1)$ & $10 \cdots \cdots$ No. \\
\hline & 93.2 & 3.4 & 3.4 & 16.9 & 66.1 & $16.9 \cdots \cdots \%$ \\
\hline \multirow{2}{*}{ A } & 16 & 8 & 35 & $6(2)$ & $9(1)$ & $44 \quad \cdots \cdot \cdot$... No. \\
\hline & 27.1 & 13.6 & 59.3 & 10.2 & 15.3 & $74.6 \cdots \ldots \%$ \\
\hline \multirow{2}{*}{$\mathrm{J}$} & 4 & 2 & 53 & $9(1)$ & $6(1)$ & $44 \quad \cdots .$. No. \\
\hline & 6.8 & 3.4 & 89.8 & 15.3 & 10.2 & $74.6 \cdots \cdots \%$ \\
\hline
\end{tabular}

つぎにD誘導で ST の異常を認めた55例の標準13 誘埒との関係は表14の通り, 標準13誘導に ST 変化 の現われ万誘導は $V_{5}$ 誘導で11例， $V_{6}$ 誘導12例， $V_{7}$

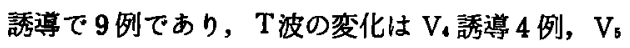
誘導 5 例, $V_{6}$ 誘導 4 例, $V_{7}$ 誘導 2 例であった。 の $\mathrm{V}_{5}, \mathrm{~V}_{6}, \mathrm{~V}_{7}$ 誘導 ST変化に, 更に ST の境界域 の変化を加えてみると， $V_{5}$ 誘導が27例， $V_{6}$ 誘導 36 甽, $V$ 誘導41例となり，V，誘導に最も変化が現わ れやすい.
表14 D誘導 ST 異常例 (55例) と 標準13誘導の関係

\begin{tabular}{|c|c|c|c|c|c|c|c|c|c|c|}
\hline & & I & II & $\mathrm{aVl}$ & $\mathrm{aV}$ & $V_{3}$ & $V_{4}$ & $V_{5}$ & $V_{6}$ & $\mathrm{~V}$, \\
\hline \multirow{3}{*}{ ST } & I & 3 & 5 & 3 & 4 & 0 & 4 & 11 & 12 & 9 \\
\hline & II & 15 & 26 & 8 & 22 & 0 & 1 & 16 & 24 & 32 \\
\hline & III & 37 & 24 & 44 & 29 & 55 & 50 & 28 & 19 & 14 \\
\hline \multirow{3}{*}{$\mathrm{T}(\mathrm{U})$} & I & 1 & 1 & 1 & 1 & 2 & 4 & 5 & 4 & 2 \\
\hline & II & 2 & 3 & 0 & 1 & $3(2)$ & $7(3)$ & $5(1)$ & $4(1)$ & 5 \\
\hline & III & 52 & 51 & 54 & 53 & 48 & 41 & 44 & 46 & 48 \\
\hline
\end{tabular}

I : abnormal group

II : borderline group

III : normal

運動負荷後の心電図について, 標準12誘導と Nehb 誘導の此較は表 8 の後半に示す通りで, 標準12誘導 では61例が異常，47例が境界域，25例が正常であっ たが, Nehb誘導心電図についてみると, 異常を示 すのは90例（うちD誘導の ST変化を示すものは89 例）, 境界域のものは31例, 正常のものは14例であ った．てのように安静時心電図と同樣, “異常出現率、 は Nehb 誘導心電図に扔いて, 標準12誘導心電図上. りも骨度であった。 
Fig 3 19才 健康女子
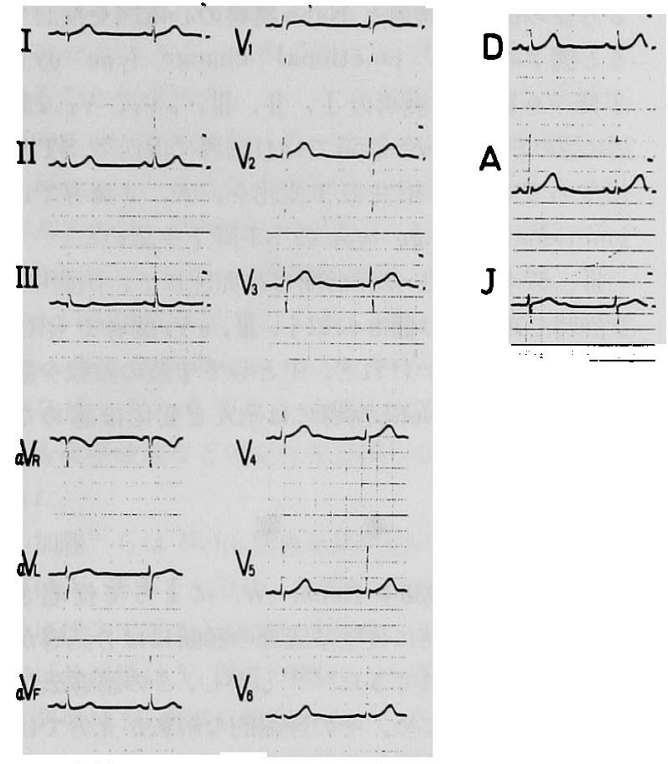

Fig 420 才健康男子

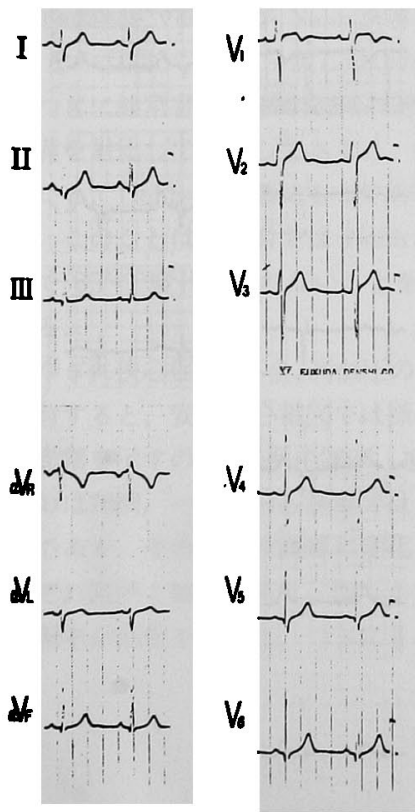

D

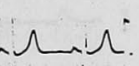

A
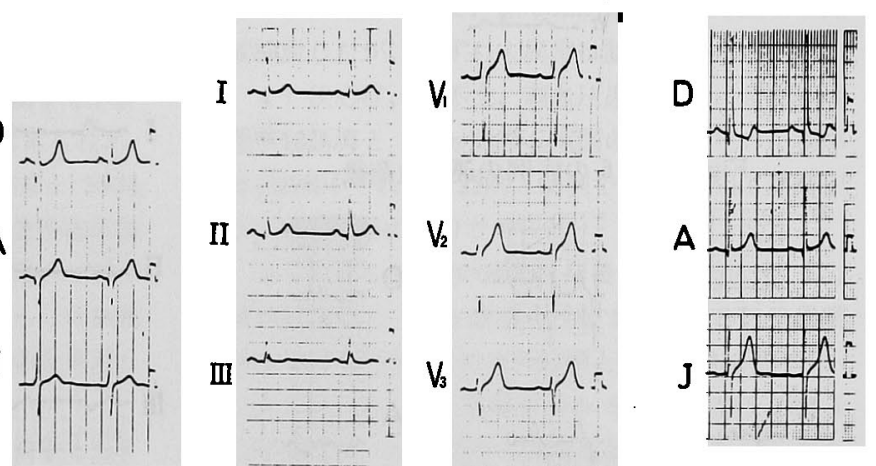

Fig5 59才 男性 狭心症

b ) 異常例

I，56才男性. 臨床診断は狭心症. 本症例は明ら かな狭心発作を有するが，安静時心電図は図 5 の如 くで，標準13誘導には QRSの high voltage を認 め, $\mathrm{TV}_{2}\left(19 \mathrm{~mm} /\right.$ 達する $\left.{ }^{71}\right)$ に比較して $\mathrm{TV}_{5}, \mathrm{TV}_{6}$ は 低いが，いずれもT波は陽性で，ST の変化は全く 認めない，本例の Nehb 誘導をみると明らかにD誘 導に ST の降下，T波の干の二相性を認める。

II. 56才男性で臨床診断は狭心症. 安静時心電図 は图 6 の如くで,標準13誘導に殆んど異常所見なく， Nehb 誘導ではD誘導にST の降下を認める．本例

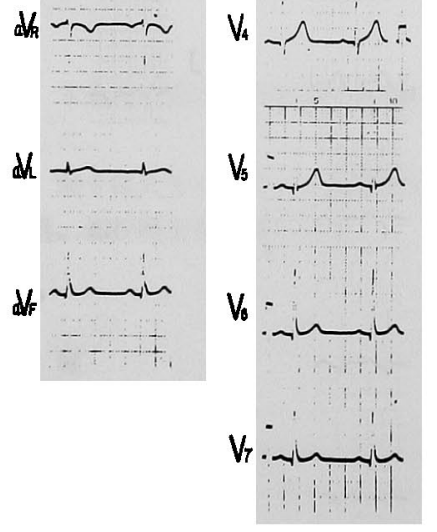

4) 症 例 年男女80例の標準12誘導と，Nehb誘導を記録し， 検討したが，これらの80例は標準12誘導は勿論，D 誘導にもST変化を認めるものは 1 例もなかった。 これらのうちの代表的な症例を図 3，4亿示す．図 3 は19才の健康女子であり, 図 4 は20才の健康男子 であり D誘導にQ波をみる正常例である。 


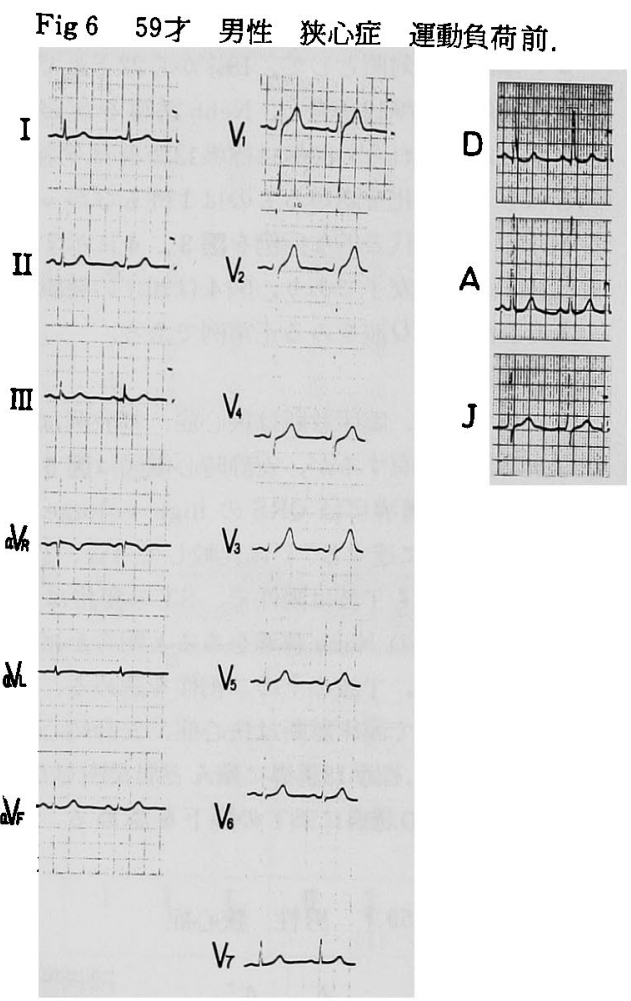

に対して Master $の$ double two-step testを行い, 3 分後の標準12誘導と Nehb 誘導の心電図を検討す ろと图7の如く, junctional change type $の \mathrm{~S}$ $\mathrm{T}$ 降下を標準 12 誘導の I, II, III, $a V_{F}, V_{2-6}$ 誘 導に認めろが，Nehb誘導ではD誘導に虚血型 ST 変 化ならびに干二相性の T変化を，A，J誘導では junctional change typeの ST降下を認めた。

III. 67才の女性.臨床診断は高血圧にて, 治療中. 安静時心電图では図 8 の如く, III, $a V_{F}$ 誘導で $Q R S$ の voltageは低いけれど, 主としてT波の陰転を認 めろ.しかし，Nehb誘導には殆んど変化は認めな い.

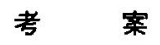

Nehb 誘導は1938年 Nehb.W．によって提唱さ れ, 心筋硬塞, 特に後壁基底部の診断には D誘導が 有用であるとされてきだ,9,10) しかし，ての誘導法が 双極誘導であるため，その理論的な解釈が充分では なく，経験的な検討のみがなされてきた．著者は第 一編において人体胴体模型を用いて, 本誘導法の理

Fig 8 67才 女性 高血圧症.

Fig 7 図 6 の症例の運動負荷後.
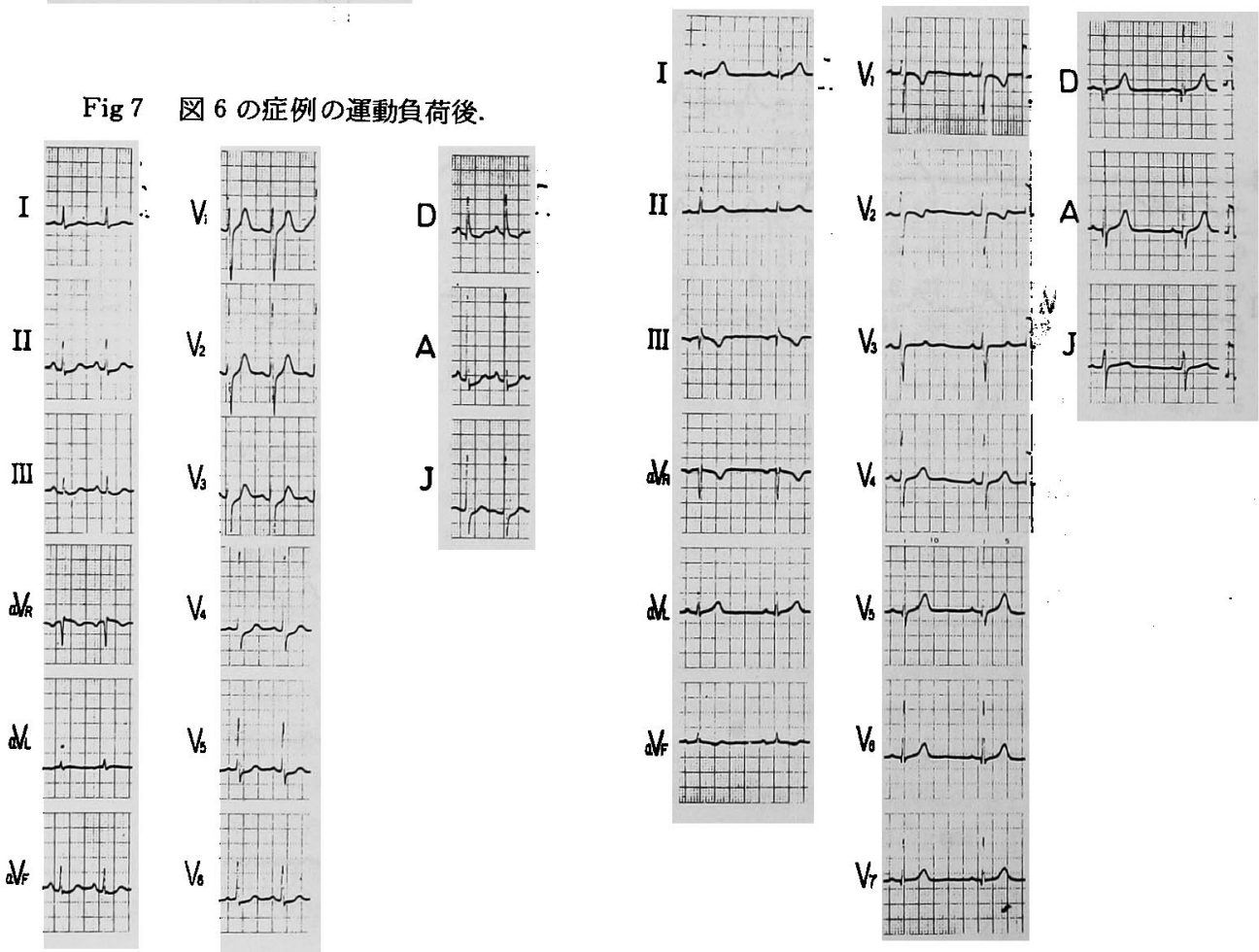
論的背景を検討した，その結果，Nehb誘導のD誘 導が $V_{5}, V_{B}, V_{7}$ 誘導よりも transfer impedance

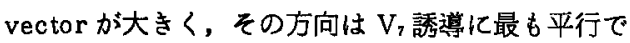
あることを認めた．ところで ST変化は $V_{7}$ 誘導の 方向に平行的ではあるが， $V_{7}$ 誘導そのものは,大き さが小さいため臨床上 ST 変化を見つけにくい欠点 があろので，ST変化を早期に，かつ確実に見つけ ろためにはNehb-D誘導が有用と推察した。一方 Nehb-D誘導は必ずしもII，III，a $V_{F}$ 誘導とその transfer impedance vector が平行でないとと明 らかにした。このととは臨床的にはD誘導は必ず しも後壁硬塞などの変化を表現しないととが示唆さ れた.

加藤 ${ }^{111}$ らは Nehb 誘導を臨床的に検討し A，J誘 導は $V$ 、誘導で十分に，D誘導は $V$ 誘導で比較的十 分に代表出来ると結諭している，しかし著者の検討 では $\mathrm{D}$ 誘導は $\mathrm{V}_{7}$ 誘導に類似し，A誘導は $V_{5}$ 誘導に, $J$ 誘導は $V_{3}$ 誘導に類似するが，それは約半数の症 例であった。また R波の高さは明らかに D誘導が

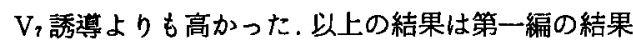
を裏付けるものである.ST-T変化については，あ まり標準肢誘道との間に類似する誘導を認めなかっ た．そのことは一つには標準肢誘導の transfer impedance vector が Nehb誘導のそれよりも小さ く,その方向が完全に一致しないためと考えられた。

つき化常者80例を対象として標準12誘導と Nehb 誘導を対比して検討してみると, 標準12誘導は勿論 のとと, Nehb-D誘導にもSTの変化は認めなかっ た.このことは健常者では Nehb誘導, とくにD誘 導で ST-T変化か現れないととを示すものと考えら れる。

つぎに狭心症, 冠不全, 高血圧の患者を対象として 検討すると, 安静時心電図では標準13誘導は ST-T の異常を示すのは136例中26例, 境界域の変化を示 すのは70例，一方 Nehb誘導ではそれそれ59例，48 例であり，そのうちD誘導に変化を示すものは，そ れそれれ5例と35例であり，明らかにD誘導における 出現率が高度であった。つぎにII, III, $a V_{F}$ 誘導に
のみ異常を示すもの 5 例，境界域の変化を示すもの 8 例の Nehb誘導との関連性を検討したところ, Nehb 誘導に変化を恝めたものは少数であった。こ のととは第一編における理論実騟の結果とよく一致 した. 更に, ST-Tの変化の追求には運動負荷試験 が臨床上重要なととであるので, Masterの double two-s tep testによる運動負荷試験を行ったところ， 標準12誘導では61例に異常を認め, Nehb誘導では 90例に異常を認めた。このてとは Nehb誘導法が, ST の変化をより早期に, 適確に検出する るのであ るととを稟付けたものと考える。

\section{結 語}

第一編の結果に基き，Nehb誘導の臨床応用の有 用性を検討した。

1) Nehb誘導のD誘導は $V_{7}$ 誘導に，A誘導は $V_{5}$ 誘導に，J誘導は $V_{3}$ 誘導にそれそれ約 $50 \%$ 類 似性をみられた。

2) Nehb 誘導の QRS 棘皮の形はD誘導は $q R$ 型, A誘導は qRs．RS，qRS 型，J誘導はRS 型が多 かった。

3 ) 健常者80例で, 標準12誘導と Nehb 誘導を比 較検討したが，いずれも異常は認めなかった。

4 ) 狭心症, 冠不全, 高血圧患者では, 安静時の 標準13誘導と Nehb 誘莩心電図の ST 変化の出現率 は136例中それぞれ22例と55例であり，Nehb誘導が ST 異常発現に有力であった。

5 ）乙れらの患者の運動負荷後の心電図について, 標準12誘導と Nehb 誘導を比較すると，ST-T 異常 出現率は136例中それぞれ61例と90例であった，

6) II，II，a $\mathrm{V}_{F}$ 誘導にのみ ST-T異常を認める 心電図では Nehb 誘導で異常を認めろととは少なか った.

本論文の要旨は第37回日本循環器学会総会で発表 した.

稿を終えるに当り，小坂教授之原岡助教授の御指 導, 御校閲を深謝致します.

文献

1 ) Nehb. W: Das Brustwand-Elektrokardiogramm. Dtsch. Ges. Keislaufforsch, $12: 177,1939$.

2 ) Nehb. W: Zur Standardisierung der Brustwand-ahleitungen des Elektrokardiogramms. Klin.

Wshr. $17: 1807,1938$. 
3 ） 戸山靖一，鈴木恵子：心電図運動負荷試験. 日本臨床，28：2577，1970.

4) 千田信行：向老期以後におけろ啸康診断の判定基準について. 日本老年医学会誌， $7: 147 ， 1970$.

5 ) Lepeschkin, E., and Surawicz, B.: Characteristics of true-positive and false-pasitive results of electrocardiographic Master two-step exercise tests. New Eng. J. Med., 258 :511, 1958.

6) 新谷博一, 成沢達郎, 井上康平, 杉田幸二郎, 木村三津夫, 石井靖夫：㹨心症の心電図診断. 臨床と研究, $39: 1134,1962$.

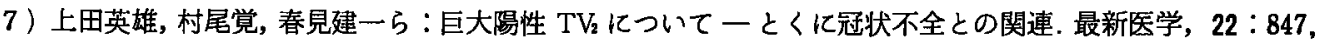
1967.

8 ) Laurentins, P., and Bülow, G.S.: Der diagnastische Wert der DAJ-Ableitung nach Nehb in vergleich zur Wilson-und Extremitäten-Ableitung bei Herzinfarkten. Klinische Wochenschrift. $31: 612,1953$.

9 ）難波和, 小沢舜達, 豊川幸子：Nehb 誘導心電図について。棕合臨床, $3: 37,1954$.

10）新谷博一：心筋硬塞の心電図（第 7 報） Nehb 誘導に就て。 日循誌，19：23，1955.

11）加藤亮, 機部竹飛虎, 平井智, 長谷川義夫：Nehb誘導法の単極誘導法的考察. 名古屋医学誌, $70: 115$, 1955. 


\section{Studies on the Nehb Lead System \\ Part II a clinical significance \\ of the Nehb Lead System}

By

\section{Nobuhiko Yonahara}

The First Department of Internal Medicine, Okayama

University Medical School

(Director: Prof. Kiyowo Kosaka)

A characteristic of the Nehb lead system and especially a value of the lead Nehb-D were studied in 136 subjects

1) The lead Nehb-D was similar to the lead $V_{7}$, the lead Nehb-A to the lead $V_{5}$ and the lead Nehb-J to the lead Vs. Those similarities were about 50 per cent each.

2) On a form of QRS complex of the Nehb lead system, the lead D was mostly qR type. The lead A was mostly qRs, then RS and qRs type in order of frequency. The lead $J$ was mostly RS type.

3) The electrocardiograms of 80 healthy men were all normal both in the standard lead system and in the Nehb lead system.

4 ) The number of cases of abnormal ST changes at rest were 22 in the standard lead system and 55 in the lead Nehb-D out of 136 cases.

5 ) The number of abnormal ST-T changes after exercise tests were 61 in the standard lead system and 90 in the Nehb lead system.

6 ) In the cases with abnormal ST-T changes only in the leads II, III and aVf, the abnormal ST-T changes of the lead Nehb-D were a few. 